\title{
York Guilds and the Corpus Christi Plays: Unwilling Participants?
}

Almost a century ago Maud Sellers commented regarding the Corpus Christi pageants of York that the 'sorely burdened craftsmen' who staged them 'found the upkeep of the plays an intolerable and vexatious burden'. ${ }^{1}$ Miss Sellers' remark deserves to be explored, for some scholars continue to suggest or imply that the York plays were found onerous, an unwelcome financial burden placed upon unwilling citizens of the city by the mayor and corporation that controlled their guilds. ${ }^{2}$ Heather Swanson, for example, exposes a lack of perspective in her remark that the " $\mathrm{c}$ ] raft guilds took a rather more jaundiced view of the pageants, because of the expense they entailed'. ${ }^{3}$ There is, of course, sufficient evidence of guild resistance if we look at the ways in which the plays were funded, in part through a system of fines divided between support of the pageants and of the corporation. Then, craft guilds ordered to contribute to others' pageants were often unenthusiastic, as shown by the heavy fines with which they were threatened if they did not pay their allotted shares. Refusal to pay the required subsidies and pageant money, or even 'grudgyng or gevyng any evill woordes', was treated as rebellion against authority. ${ }^{4}$ There were also individual cases of complaint about the cost of the plays to which a company had been assigned, for how could it be otherwise in the declining economy of a town in which severe shifts in social structure and a shrinking population were occurring during the latter part of the fifteenth century as well as the beginning and middle years of the sixteenth century? The remarkable fact is the tenacity of the local citizens in maintaining their pageants through two centuries - through dearth, disease, poverty, and death as well as turbulence due to the national regime change, the Wars of the Roses, sundry catastrophes such as the collapse of the Ouse Bridge in the 1560s, and a change of religion as well as severe inflation in the middle of the sixteenth century.

York's decline has been described as 'catastrophic', with its population at a high of around perhaps as many as 15,000 in the early years of play production at the end of the fourteenth century but dropping to little over half of that number in the middle of the sixteenth century. ${ }^{5}$ In the 1520 s, the 
wealth of York, which regarded itself as the second city of the realm after London, seems to have been reduced to fourteenth among provincial towns, below that of Lavenham, Suffolk. ${ }^{6}$ Already by 1431-32 the Goldsmiths were pleading poverty and asking for relief, while the Leather-workers and other metal craftsmen would by mid-century have begun a period of serious decline, judging from the entries in the freemen's rolls. ${ }^{7}$ By 1491-2, a letter from King Henry VII indicates that he has been 'credibly informed that our Citie of York in divers placs and parisches theroff is fallen into suche extreme ruyne and decaye, as the inhabitaunts therof, fewe in nombre and of exile havour, be not of powre to be contributories and to bere suche chargez in thyngez to be cessed for us generally in our said Citie as they have doon of tyme passed'. 8 As in other English provincial towns, the sixteenth century did not begin auspiciously, and some crafts never recovered. ${ }^{9}$ In 1561 the Painters pleaded that they were now but 'poore men' and hence were being overcharged for their share in the play of Crucifixio Christi, or the play of the nailing of Christ to the cross, that they shared with the Pinners, ${ }^{10}$ and in 1569 the wax chandlers, who had once been so important for the practice of traditional religion with its heavy use of candles in religious rites, begged the corporation for 'ayd' toward the cost of 'bryngyng forth' their pageant of the Offering of the Magi since their 'Craft is moch decayed'. ${ }^{11}$

While York maintained many fine houses and beautiful churches for which it was renowned, after the middle of the fifteenth century there developed a strong sense of encroaching civic impoverishment. By 1553 a royal commission could report 'the long and great decay of the sayd Citie and of the howses and dwellyngs within the same stondyng desolate and voyd of inhabitaunts'. ${ }^{12}$ The sledmen in the same year surely were not bluffing when they complained to the city council that they were not able 'to bryng forth' their pageant of Peregrinus, dramatizing the story of the travelers to Emmaus, 'by reason of their pouerty' as they have customarily in the past since their pageant wagon 'is now farr in decay and broken', whereupon this play was ordered to be given over to the Wool-weavers who were to leave off playing the far more elaborate Assumption. ${ }^{13}$ Likely, judging from the entries in the Ordo paginarum, those who took up the play were in fact dealers in wool, for there they are referred to as Wool-packers. ${ }^{14}$

By then the reduction of numbers and affluence of the guilds associated with the clothing industry had long ago decimated the engine of the town's economy. In 1561, only a very few weavers were observed to be present in the municipality, 'very poore men nowe remaynyng', while 'in olde tymes past the said Citie [of York] hath moche prospered in clothe makyng'. ${ }^{15}$ 
The dropping of the performance of the Drapers' pageant of the Death of the Virgin in 1548, 1549, and 1551 may, however, have had less to do with the depletion of the guild than with the reformation objection to seeing Mary as the mother of God, while the refusal of four drapers, described as obstinate, to the support of the play in 1554 was undoubtedly due to their rejection of traditional religion. ${ }^{16}$ Their defiance was regarded by the corporation as a very bad example indeed since it would involve 'the great encoragyng of suche lyke wilfull persons and disordre in the sayed craftes' ${ }^{17}$ Other guildsmen also failed to participate at this time, as the records indicate, and in the case of the Scriveners' Doubting Thomas John Meltynby was given an extra stipend since in bringing forth this play he had 'none to bere with hym in the ... Charges'. ${ }^{18}$

Another factor, not previously to my knowledge noted in discussion of the York plays, was the prevalence of disease and epidemic throughout their entire history. These vastly compounded the town's problems, for its population, in order to maintain a reduced strength of numbers, was required to draw immigrants from the surrounding countryside and even from the continent, and these newcomers needed to be amalgamated into the social structure which supported the plays. ${ }^{19}$ This local change gives credence to Chester Scoville's suspicion concerning the citizens' 'fear that the world outside York was in constant danger of overcoming their civilization' ${ }^{20}$ and reinforces the importance of the plays to both the corporation and the guilds in affirming their identity in the midst of an ongoing population crisis. York's birth rate, as in other English towns, did not match the death rate. Possibly as many as half of the newborns failed to survive into adulthood, old age generally was held to begin at around forty years of age, and very few lived to be sixty. New blood was thus constantly needed and, in periods of sickness, was still not sufficient to keep the population from declining. ${ }^{21}$ Towns quite simply were more prone to disease than sparsely populated rural areas, and the kinds of disease were to be sure more varied than we might at first suspect. Archaeological research summarized by Christopher Dyer indicates that, as in rural African villages today, intestinal parasites seem to have been endemic in some locations. ${ }^{22}$ If present at York, this, like the shortage of nourishing food, would have been responsible for weakening resistance to other disease.

In some years no Corpus Christi pageants - or the normal substitutes, the Pater Noster Play or the Creed Play - were played. Thus there were no plays in 1550, while in 1552 the York House Books recorded the order 'to thentent the better to avoyde assembles of people as this present within the sayed Citie beyng dangerouse for the sayd sykenes it is therfor aggreed that the billettes [i.e., the orders given to the individual guilds for their pageants] latly 
delyuered forth for Corpus christi lake shall be incontynently called in ageyne and not to be played this yere'. ${ }^{23}$ There may indeed have been more missed years than are indicated in the extant dramatic records, since conditions were capable of being truly abysmal in the summer in times of seasonal epidemic.

Following the appearance of the Black Death in 1348-9, plague and other diseases often afflicted York and other locations in England, especially following failed harvests. ${ }^{24}$ In 1378-9, not long after the initial notice of a house for a Corpus Christi pageant wagon at York, ${ }^{25}$ a widespread 'foul death' appeared throughout northern England, ${ }^{26}$ though it is not known if it afflicted the city. But in 1391 York was struck by a fierce epidemic of dysentery which caused widespread deaths, reported in Thomas Walsingham's Historia Anglicana to number eleven thousand, which must of course be a gross exaggeration. ${ }^{27}$ Particularly bad was the period $1433-40$, when in some years failed harvests due to cold weather severely affected the food supply and drove up prices. High prices meant that the malnourished poor became particularly vulnerable to disease and hence helped to spread the infection. ${ }^{28}$ Indicative of an effort to compensate for the depletion of the population, the Freemen's Register lists an unusual number of entries into the freedom of the city around the years 1439-41 and shortly thereafter. ${ }^{29}$ The diseases prevalent in these early years, as would be the case later, are difficult to identify since generic terminology is often applied and since the ordinariness of pestilence made it liable not to be noticed in the York records. 'Plague' could be either bubonic or pneumonic, but it also might designate influenza, typhus, smallpox, pneumonia, or dysentery. ${ }^{30}$ While somewhat better years followed, England was not to be free of epidemic disease, and the latter part of the fifteenth century, as noted above, marked its fierce return. Epidemics were recorded at York in 1485, 1493, and 1501, and some of these years may be correlated with food shortages, which, as noted, had dire consequences for the health and well-being of town residents. ${ }^{31}$ Crises had indeed occurred in the winter of 1493-4 when the sweating sickness had caused the city to be in 'miserable ruyne and decaye' due to 'the lamentable plage of pestilence by whiche many ar decessed and many for fere of the same departed', ${ }^{32}$ and in 1501 a pestilence was reported that may have been a local outbreak but coincided with harvest failure and epidemic of 1500-02 elsewhere in England. ${ }^{33}$ In 1538 a return of 'playg called pestyllence' was reported in the York civic records. ${ }^{34}$

Usefully, the pattern of disease and epidemic has been charted for the Tudor period by D.M. Palliser. ${ }^{35}$ The illnesses that caused such disruption in the early 1550 s were described as 'the playg of pestylence'36 and, along with other disease, involved the return of the sweating sickness, apparently a 
particularly virulent form of influenza, no doubt caused by a virus very like the H1 strain involved in the influenza epidemic of 1918. The York historian Francis Drake reported: 'People in the best state of health ...were the most liable to be seized by it; and at first was certain death to them in twenty four hours time. ${ }^{37}$ The figure of Death, speaking to the Artificer in Lydgate's Dance of Death more than a century earlier, had reflected the potential for the rapid onset of fatal disease when he said, 'My strook is sodeyn / fro which no man may flee'. ${ }^{38}$

Typhus may also have been present, believed to have been brought to the town by a contingent of German soldiers, who had come to York in November $1549 .{ }^{39}$ The epidemics, which again followed in the wake of exceptionally bad harvests nationwide, ${ }^{40}$ involved a high mortality rate, claimed to take away half the population, ${ }^{41}$ and then again in 1563 it was said that the population dropped by a third. Palliser quotes a previously unpublished record transcribed from a letter directed to the earl of Westmorland which noted a visitation of an 'extreame and farvent sekenes' in August 1558.42

What is most remarkable, then, is that the Corpus Christi plays of York survived such social, economic, and even for a time religious upheaval to continue from c.1376 in whatever form they had initially emerged to their suppression under pressure from the ecclesiastical authorities, whose attitude toward the cycle plays seems to have been no different from Matthew Hutton's well-known sneer regarding the Creed Play - that is, 'it was plausible 40 yeares agoe, and wold now also of the ignorance sort be well liked'. 43 In 1580, an entry in the House Books shows that 'the Commons did earnestly request of my Lord Mayour' and the council 'that Corpus christi play might be played this yere', ${ }^{44}$ and many guilds retained their pageant houses for storage of their wagons and equipment for many years thereafter. If the civic authorities of the fourteenth century had been responsible for latching onto the idea of plays performed on pageant wagons throughout the city on Corpus Christi as a way of rationalizing diverse crafts and occupations, as recently suggested by R. B. Dobson, ${ }^{45}$ their project clearly was successful insofar as the establishment of the drama was concerned even though the defining of boundaries for individual crafts would be less so. In 1363, a statute had demanded that 'Artificers, Handicraft People, hold them every one to one Mystery' on pain of imprisonment. ${ }^{46}$ Consistent with this order, prohibitions forbade sharing information about one's trade with others. According to the E Memorandum Book, guilds, or mysteries (referring here to the minstrels), were not to 'open or desclose anie wordes or sayinges lawfull touchinge ther sciens' to non-members on pain of a severe fine. ${ }^{47}$ As Swanson has argued, 
the assignment of each person to only one occupation was more a fiction than a fact since individuals regularly continued to pursue multiple endeavors for example, at York the Parchmentmakers and Glovers rather than the guild of Whitawyers seem to have been leaders in the preparation of tawed leather, while the Tapiters, 'the makers of worsted, not only made linen cloth but also died their own yarn'.48 The most interesting example here involves the prominent carver Thomas Drawswerd, who was retained to 'mak the pagiant of the dome ...newe substancialie in euery thing' for the Mercers in 1501, ${ }^{49}$ work that would involve a number of skills, including painting and carpentry as well as cloth manufacture and decoration, though of course some of this work would have been given over to sub-contractors.

But with regard to the plays, non-economic factors in any case outweighed economics. The play cycle, while it depended on the skills of the crafts for its wagons, costumes, and stage properties, ${ }^{50}$ was successful and long-lasting because it tapped into the religious climate of a city which, though apparently not abnormally enthusiastic about its religiosity for its time, nevertheless held firmly to a conventional but strong belief in the efficacy of the rites and practices of traditional Christianity. York, after all, would be a city that allowed itself to be occupied by the rebels for two months during the Pilgrimage of Grace in 1536, and thereafter was known for its frequently demonstrated but usually tacit support of the old religion. ${ }^{51}$ In this regard too one may mention the local reluctance to 'cleanse' the city's churches of 'idolatry' until after $1570^{52}$ and its unwillingness to inform on practicing Roman Catholics such as Margaret Clitheroe, who was betrayed not by a local but by an alien and reluctantly executed following her refusal to plead in $1586.5^{3}$

The Corpus Christi cycle, which, at least from the compiling of the Ordo paginarum in 1415 , included a range approximating the whole 'salvation history' of the world from the creation of the cosmos to the end of time, provided a means by which the citizens of the city of York could situate themselves in relation to a reality perceived as sustaining and yet judging them. The visual signs observed on the pageant wagons were in one sense conventional and consistent with the ecclesiastical art of the time, but these signs were also indicative of positional symbolism (to use the term advanced by Mary Douglas $)^{54}$ that defined the citizens and other residents and set them off against imagined or real subversives who opposed or failed to respect the moral order. The supporting text, which is all we have since we are of course unable to observe the physical scenes originally depicted in the course of the presentation of the plays, may be said to be masterful in advancing the 
positional symbolism, as embedded stage directions demonstrate. It is clear, for example, that Herod, always distinctively evil in the visual arts, ${ }^{55}$ sets up an antagonistic relationship with the audience from the start, while the crucifixion scenes, albeit subject to modern misinterpretation, were specifically designed to emphasize sympathy for the object of torture and against the distortion of the legal system that brought Jesus to his sacrificial death a death believed to be a benefit for all who are willing to take advantage of the system of salvation offered by the church. ${ }^{56}$ It was also a death, we need to recognize, that was made available to believers through the anamnesis promised in the eucharist, which was believed to bring those looking on at the rite into direct visual contact with the bread transformed into the real body of the redeemer. The function of memory thus was affirmed as a central principle that also emphasized the sense of sight, regarded as a window which in the right circumstances provided a view of eternity itself. ${ }^{57}$

This is not to claim that seeing the pageants involved pietistic excess such as what might be observed in the case of flagellant processions in southern Europe. Yet the parading of pageants on Corpus Christi, one of the holiest days of the year, albeit only recently established by the Church in England, ${ }^{58}$ would have been of a piece with the array of local art depicting similar scenes from sacred history. Unfortunately much of this art was lost at the reformation and on account of subsequent neglect, but what remains, mainly painted glass in the windows of the Minster and the local churches, is symptomatic of a broad-based effort to make salvation history visibly present and available. The depictions were mnemonic aids, like the plays themselves, and in many cases more than that. Figures such as the image of John the Baptist at the altar of the Holy Trinity in the church of St Michael Spurriergate were devotional objects, ${ }^{59}$ even more directly regarded as channels to the divine that might be invoked and venerated by worshippers. ${ }^{60}$

It is surely significant that the period when the plays were developed and for more than a century afterward was a time of great church building and church decoration, both of which involved massive expenditures by York residents toward religious display. The fifteenth century saw extensive rebuilding as well as alteration and expansion of at least eight of the citizens' own parish churches, ${ }^{61}$ and, for example, in the case of a new chapel of $\mathrm{St}$ Catherine at the Church of St Denys a generous contribution of forty shillings by William Muston, fisher, was designated in his will of $1418 .{ }^{62}$ Documents provide record of a great number of images, now lost, that include such examples as a 1449 image of Moses and an alabaster figure of St Anne as well as other figures at St Mary Magdalen Hospital and Chapel noted in an 
inventory in the will of John Clerke, and at Holy Trinity Priory a painted cloth, given by Thomas Robson in 1519, 'of th'ymage of Our Lady, with her Son sowkyn on hir breste, with a similitude of a preste knelyng'. ${ }^{63}$ Representations of the popular Our Lady of Pity appeared at All Saints, Pavement, in the south side of the Lady Chapel (will of Mary Chandler, 1521), at Holy Trinity Priory (wills of Alice Clerk, 1506, and Thomas Robson, 1519), at the church of St Lawrence (will of Matilda Gray, 1457), St Martin Coney Street (will of Thomas Hall, 1522), St Mary Castlegate, where it was said to stand in a tabernacle, in this instance called a 'clossett' (will of John Marshall, 1524), and other locations. ${ }^{64}$ One of these was an alabaster carving ('ymagine Pietatis de alabastro'), given by John Ravensthorpe to St Savior's Church in 1433 and most likely of York workmanship. ${ }^{65}$ Less specific references to candles indicative of devotional images are constant throughout the fifteenth and early sixteenth centuries but naturally come to a stop at the reformation.

If more affluent members of the community could donate expensive devotional images, contributions to lights to be placed before them in churches and chapels were within the range of all but the most humble. Some examples culled from wills, most of them unpublished, by Angelo Raine are revealing. Richard Roderham, weaver, left one shilling to a candle that was hanging in St Mary's Chapel at St Martin Coney Street in 1398. ${ }^{66}$ John Couper, carpenter, contributed to a light located before the cross and an image of the Virgin Mary at Holy Trinity Goodramgate in 1402,67 and William Hedon, mason, left a sword, two bows, and a dozen arrows to the light of St Mary at St Maurice's Church in $1429 .{ }^{68}$ John Witton, glazier, gave twelve pence toward a new tabernacle for an image of St Helen at the Church of St Helen, Stonegate, in 1451. For the same church, John Browne, founderer, gave a candlestick and wax to be placed 'afore oure Lady in the northe queere' as well as painted cloths to be completed for the altar of the Blessed Virgin Mary in $1493 .{ }^{69}$ Nicholas Pereson, dyer, left a gift of $3 \mathrm{~s} 4 \mathrm{~d}$ for two silver candelabra to be placed in St Martin, Micklegate, in 1480. Richard Croklyn, fletcher, left twenty pence for candles for the candelabrum in front of the high altar at St John Ousebridge in 1489, and John Coke, waxchandler, left five shillings to the painting around the crucifix in $1509 .{ }^{70}$ The Pinners maintained a candle in an unidentified church from the middle of the fourteenth century, while Glovers and Cordwainers were responsible for others at the Minster. ${ }^{71}$ The Marshals, Smiths, and Bladesmiths in 1580 kept a 'Corpus christi light' as well as a candle before an image or altar of St Eloi in St William's Chapel on Ouse Bridge, obligations that, along with the mainte- 
nance of their pageant, 'haue been tofore of Aunceaunt tyme' and that they wish to continue if they can ward off incursions by the Cutlers. ${ }^{72}$

While gifts of painted glass were hardly the province of the poor, the survival of much of this glass at York surely presents the best indicator of the extent to which economic resources were voluntarily directed to religious purposes. Here scenes in the parish churches range all the way from the fall of Lucifer of 1400-25 at St Michael Spurriergate and Adam and Eve in the earthly paradise of c.1375 at St Martin-cum-Gregory, to the Fifteen Signs of Doomsday (c.1410) at All Saints North Street and a fifteenth-century Last Judgment figure of St Michael weighing souls at St Mary Bishophill Junior. ${ }^{73}$ These figures in glass are not devotional images but rather are mnemonic in function, but a few are also didactic in directing the use of wealth toward good deeds or works of piety. For example, the performance of charitable acts, as commanded by Matthew 25 where the obligation is specified in connection with the Last Judgment, appears in glass of c.1420 at All Saints North Street, and in this instance the donor was an affluent parishioner, the York merchant and mayor Nicholas Blackburn, Sr., whose will would epitomize the piety of the York elite. ${ }^{74}$ These charitable acts also appeared prominently in the York Mercer's play of the Last Judgment as tests for entry into Paradise, with those who fail being consigned instead to the place of darkness. 'Say, man, what suffered pou for me?' asks Christ the Judge, who has, he reminds them, himself 'suffered swilke mischeue' on the cross $(47.266,276) .{ }^{75}$ Appearing on a rainbow before the people of the earth, he invites his 'chosen childir' into the place of 'joie and blisse' and orders the wicked to enter 'helle to dwelle withouten ende' $(47.365-7,370)$. There is every indication that service to the sick, the starving, and the destitute of the city if not to undeserving, including those vagabonds who might from time to time stray through the city gates, was widely regarded by the citizens as necessary for salvation in late medieval York. ${ }^{76}$ But the York Corpus Christi plays were in fact themselves understood to be acts of charity. One of the motives announced was that they were for the suppression of vice. ${ }^{77}$ They thus were presented not only for the praise of God and the honor of the city (and therefore requiring competence from the actors, who must not be 'insufficiant personnes either in Connyng voice or personne') $)^{78}$ but also 'for the benefit of the ...commons and of the strangers who have travelled to the said city for the honour of God and the promotion of charity among the said citizens'. ${ }^{79}$ As such, in 1417 the plays were said to be mounted 'especially for the honour and reverence of our Lord Jesus Christ and for the benefit of the ... citizens' ${ }^{80}$ 
Like the plays, the devotional images, candles, and painted glass in York churches gave symbolic significance to the religious concerns of the city of York. Yet as the extant records of these artifacts and the actual examples that survive will show, there was often an arbitrariousness about the choice of their subject matter. Donors funded those images and scenes that appealed to them in salvation history, whether biblical or of the lives and martyrdom of saints. In spite of the common medieval illusion of a city modeled on the pristine order of the heavenly Jerusalem, ${ }^{81}$ the reality could never approach anything like perfection just as the city itself was an unshapely mass of crooked and narrow streets. In Yeatsian terms, there was no chance of achieving unity of Being. It could only remain a place of Becoming. Rather than a Byzantine stasis (to cite once again a Yeatsian concept), the city displayed a route for movement - a route for pageantry, procession, and pilgrimage leading from Toft Green where the wagons for the Corpus Christi cycle assembled through the city to the Pavement in front of All Saints Church where the plays were presented at the final station. Ideally, each participating guild achieved a collective identity and place within the parade of plays through the city, from the Barkers, associated with the odorous process of tanning, with their Creation of Heaven and Earth, ${ }^{82}$ to the affluent Mercers. In so doing, each guild maintained its role of presenting an essential fragment of sacred story, often a fragment also pointing to its social and economic role in the city as in the case of the Bakers' pageant of the Lord's Supper. Just as no meal could be considered truly complete with bread alone, so the Bakers' pageant was part of a parade demonstrating the necessity of spiritual food for the onlookers. And, we need to remember, the bread shown in this pageant was the central item in the Eucharistic meal - the item most essential to the spiritual nourishment of the parishioners and the object of the greatest devotion at its consecration in the parish church. The actual consecrated bread also was the object carried through the streets as the focus of the Corpus Christi processions that were maintained along with the plays on Corpus Christi day or, in the case of the civic procession at York from the latter part of the fifteenth century, on the day following. But it was the Bakers' play that fully dramatized the event of the first eucharist and made it visible as an achievement of cultural memory beyond the abilities of any medium of the visual arts unassisted. As Pamela M. King has noted, speech provides cues to action, and 'that action ...was circumscribed by the requirements of Christian iconography to produce plays which are a living book'. ${ }^{83}$ The event in this case, made real so far as the actors were able to manage, was the symbolic institution of the sacrament itself. When such issues are understood, it is less hard to see why the York 
cycle persisted for approximately two centuries and why individual guilds, sometimes in times of great hardship, carried on. If the elite of the city were initially responsible for the assignment of the plays to the guilds, as Dobson suggests, ${ }^{84}$ the pageants could not have been maintained through coercion alone. Crucially, the guilds had adopted the plays as an important part of their self-identity and of their perception of their participation in the larger reality of salvation history.

In some cases, the choice of plays was very appropriate because individual guilds were well equipped to provide required properties and costumes, sometimes even serving to display the goods normally offered by them. This was so in the instance of the Bakers' pageant that has been cited above. In this category also were such pageants as the Tanners' Creation and Fall of Lucifer with its requirement of an evil smelling hellmouth, the Armorers' Expulsion, the Shipwrights' Building of Noah's Ark, the Fishers and Mariners' Flood, the Taverners' Marriage at Cana, the Tapiters and Couchers' First Trial before Pilate with its dream of Pilate's wife and a bed 'arayed of pe best' for her (30.153), and the Butchers' Crucifixio Christi. ${ }^{85}$ In other cases, the choice of play drew on special devotions which individual guilds had adopted. The Assumption of the Virgin was assigned to the Weavers, described in 1400 as 'the Guild of the Blessed Virgin Mary of the Weavers of the city of York', ${ }^{86}$ and the Resurrection was given to the Carpenters, identified with 'the Holy Fraternite of the Resurreccion of Our Lord' ${ }^{87}$

An exceptional case would seem to be the pageant of Fergus, named after the Jew who attacked the bier of the Virgin Mary during her funeral procession. This play was apparently genuinely unpopular with its producers, and whenever possible they would seem to have failed to bring it forth. In 1431-2, the Masons complained that their play, 'in which Fergus was beaten', was not based on scripture, and besides it 'used to produce more noise and laughter than devotion'. ${ }^{88}$ It was claimed that fighting and quarrels tended to break out, probably on account of a play text that encouraged audience reaction inflamed by anti-Semitism. By 1475-6 this unpopular play had fallen to the Linenweavers, who were to present it 'perpetually ... at paire propir Costes and expenses'; all the owners of looms for the manufacture of linen cloth were assigned a set amount and masters eight pence toward the pageant. ${ }^{89}$ However, in 1485 , following a dispute, 'the padgeant called ffergus late broght furth by the lynweves' was to 'be laid apart', though curiously in the next year they were fined for failing to present it and the guild's association with the play appears again in 1518 , when they are to have the assistance of the Woolen Weavers if they in fact 'play or cause tobe played the pageant 
somtyme called Vergus pageant'. ${ }^{90}$ It was no longer being staged by mid-century. Also by then the Drapers were to be 'dischardged of settyng forth theire olde pageant called the Dyeng of our lady', clearly in Protestant times considered, along with the plays on the Assumption and Coronation, to be unsatisfactory for presentation. ${ }^{91}$ But Fergus's earlier checkered history, I think, provides some important negative documentation, for it demonstrates the necessity of willingness to play on the part of the guilds for the continuance of the play cycle.

Other sources of tension between the city corporation and the guilds figured more prominently than conflict over the plays. In particular, there was the matter of the searchers whose task was to maintain quality control and to see that craftsmen were not encroaching on others' occupational territory. These had the ability to levy fines, and hence they represented a truly unwelcome authority that was undoubtedly open to corruption. Better times in the early fifteenth century meant civic peace, but as the economy soured conflicts also arose over a number of other issues, in the $1480 \mathrm{~s}$ including such matters as the cleaning of the streets, the sale of poultry at the Thursday Market only, and the purchase of (rather than appointment to) the offices of esquire and common sergeants. ${ }^{92}$ In 1516-17, riots broke out between crafts and merchants over the power and constitution of the city government. ${ }^{93}$ Under an oligarchic structure such as the one that governed York, the descent of political discourse into 'altercation and insult' 94 should not be surprising. The imposition of authority, often seeming to be arbitrary and benefitting the elite, was not calculated to generate civic quiet in less than good economic times, but paradoxically it also verifiably was crucial to the functioning of the city as a municipality and to the prevention of larger conflicts that would have endangered community cooperation in the plays. If the city elite were exploitive, the craftsmen received something back in return. ${ }^{95}$ The most explosive civic conflicts, such as the rioting over precedence by the Cordwainers and Weavers, could eventually be resolved, in this case by arbitration that designated the Cordwainers to march on the right and the Weavers on the left in the Corpus Christi procession. ${ }^{96}$ The Corporation, then, often was forced to balance such conflicting issues, which thus might involve the perceived reputation of the individual guilds in the city, as well as to attend to matters of trade and industry, importantly by seeing to the maintenance of quality in products being produced. Less popularly, the Corporation controlled wages. ${ }^{97}$

One might, however, question the effectiveness of the Corporation in maintaining its authority in other efforts such as keeping the streets clean, no 
small matter for the presentation of the civic plays on Corpus Christi. The poor state of the streets and the lack of sanitation are well documented. Refuse was a problem..$^{98}$ Butchers were frequent offenders, and also scavenging pigs seem to have roamed at will in spite of the Corporation's efforts at controlling them. ${ }^{99}$ The effect on health of overcrowding, latrines with their cesspits located back of houses, open sewers, and careless treatment of human and animal waste was recognized, to be sure. The Act for the Re-Edifying of Towns passed by Parliament in 1540 complained of decay in York and other declining municipalities as afflicting secondary streets and 'vacant grounds', many of them 'replenished with much uncleanness and filth ...to the great peril and danger of the inhabitants and other the king's subjects passing by the same'. ${ }^{100}$ Such unsanitary conditions engendered flies, pests, and unhealthy odor, described in the York Memorandum Book as creating 'great corruptions and horrible and pernicious air. ${ }^{101}$ In spite of efforts at paving the principal streets, there were reports of mud and mire along the main route where both the civic Corpus Christi procession and the plays would pass. Of course, for a major feast, as also for a visit from the king or other dignitary, the streets were ordered to be cleaned, reeds to be laid down, houses to be prepared for the occasion, and, at Corpus Christi, scaffolds needed to be set up at the assigned places for seeing the plays. ${ }^{102}$

One of the conclusions that must come out of any survey of the civic context at York is that the performance of the plays cannot be separated from the conditions that prevailed in the municipality, including in times of epidemic or harvest shortfall. If it has been imagined that the same persons played the same roles year after year, or that guilds had similar resources from one year to another, such notions must be revised. Turnover among players would have been inevitable, and to be sure this may help to account for the relatively short length of each of the York plays, for with such limited roles the lines might be more easily mastered by new actors required to step in. The population was demonstrably less than stable through many of the years in which the cycle was mounted, and hence one can hardly wonder if not all the pageants were played in a particular year. The important experiment under the umbrella of Records of Early English Drama and Poculi Ludique Societas with the mounting of all the York plays at four stations at the University of Toronto in 1998 illustrated the impossibility of fitting all of them between dawn and dusk if played at the larger number of stations specified in the York records. The notion that the plays would be able to continue into the night is not credible. An order of November 1427 only affecting aldermen and council members required them to 'have a lantern with a light therin burnyng 
over ther gate dores evere nyght from $\mathrm{v}$ of the clock of the nyght unto ix of the clok', and street lighting was not generally enforced until around $1580 .{ }^{103}$ The availability of nearly fifty pageants at York may thus deliberately have been a superfluity, allowing for fewer than the full number to be presented each year. The desire of the corporation for completeness in telling the story of the events of salvation history in so many pageants, including the Linenweavers' Fergus over which they attempted to exercise their authority, can hardly have been an obtainable wish.

It is indeed interesting that the Register (British Library MS. Add. 35,290), a manuscript of more than five hundred pages which contains the texts of the pageants, appears to date from the 1470s, a decade noted across England for unusually virulent epidemics - the stich, bloody flux or dysentery, possibly pleurisy and plague ${ }^{104}$ - though it is not known which of these specifically afflicted the city of York. One may speculate that in a time of population fluctuation the corporation may have decided to collect playscripts that it felt otherwise might be lost, and if there was an effort to exercise more control at this time, this would not necessarily have meant that the guilds were finding the playing of the pageants to be onerous, even if paying for them and for other civic expenses could at such times truly be a burden.

As also shown by the evidence of support for ecclesiastical art in parish churches that has been cited above, the citizens of York, residents of a community in which life was all too frequently punctuated by suffering and death, would have been surprised by the claim that they were unwilling participants in the Corpus Christi plays or the suggestion that they were victims of the city elite in this regard, though admittedly they were exploited by them in various ways. For the members of the guilds the effort of staging the events of salvation history culminated in what must have been one of the longest runs of in historical times of a drama cycle, albeit not without changes in texts or content of the cycle as it was staged. Regarding the religious faith that upheld this endeavor even for some years into Protestant times, Palliser remarks that it was indeed 'necessary throughout the period to make the suffering bearable'. ${ }^{105}$ But in spite of it all, we must not assume that life was simply characterized by a Hobbesian grimness any more than that it was a period of pure fun and games, the 'merry England' of popular imagination. At the great festivals such as Corpus Christi there was certainly enthusiasm for the mounting of the spectacles, the plays, the processions. ${ }^{106}$ Think for only a moment of the glorious and uplifting music that accompanies the pageant of the Assumption of the Virgin on folios $235^{\mathrm{v}}-236^{\mathrm{r}}, 238$, and $241^{\mathrm{r}}-242^{\mathrm{r}}$ of the manuscript. ${ }^{107}$ If we consider how this earthly life was 
considered to be transitory, ${ }^{108}$ any close reading of the playtexts themselves must reveal, even in the midst of episodes of pain and suffering as in the crucifixion pageants, a great joy and a promise of deliverance.

These were not didactic plays that preach about doctrine. They represent 'lay spiritual interests rather than a strictly clerical agenda', as Lawrence Clopper has argued, ${ }^{109}$ but as such the pageants also represent a communal project for maintaining the cultural memory of events in salvation history seen to be immensely comforting to the people and to make these events visible to them through the acting of living players. They are part of the same set of civic concerns, shared by the elite and the craft guilds, that placed such emblems of their spirituality in painted glass as the Arma Christi panel formerly in St Saviour's Church and now in All Saints Pavement. ${ }^{110}$ Here are shown the numerous wounds of Christ's body (but not in this case the wounds in the hands and heart) as well as the instruments of the passion - the cross, the gown and dice, the crown of thorns, spear, the sponge and container for vinegar and gall, the hammer and nails, the whips for the scourging, the pincers for removing him from the cross. The passion symbols were held by angels in the Mercers' Doomsday pageant, but they were also commonly the focus of meditation and devotion across all the divisions of class and economic status. That such symbols could be a source of comfort and joy also suggests a profound difference from our own time in what too must have been the reception of the plays when staged in the streets of York. The plays, and the parading of the host through the streets of the city, served then to transcend the present moment, unhappy as it might have been in the periods of deprivation and epidemic that so often afflicted the city of York in the heyday of its remarkable display of pageants that reinforced the collective memory of times past and made them relevant to contemporaries.

\section{Notes}

1 Maud Sellers (ed), York Memorandum Book A/Y, 2 vols, Surtees Society 120, 125 (Durham, 1912-15), 2:xliii. For the Corpus Christi pageants, see Richard Beadle (ed), The York Plays (London, 1982); references to the plays are to this edition and are given in my text parenthetically by play and line numbers.

2 See, for example, John C. Coldewey, 'Some Economic Aspects of the Late Medieval Drama', in Contexts for Early English Drama, John C. Coldewey and Marianne G. Briscoe (eds) (Bloomington, 1989), 77-101, and, for a discussion 
of the relation between the guilds and the plays that focuses on economic matters in a related manner, Sarah Beckwith, Signifying God: Social Relation and Symbolic Act in the York Corpus Christi Plays (Chicago, 2001), 42-55. For recent discussion of the role of the Corporation, see Alexandra F. Johnston, 'The City as Patron: York', in Paul Whitfield White and Suzanne Westfall (eds), Shakespeare and Theatrical Patronage in Early Modern England (Cambridge, 2002), 150-75.

3 Heather Swanson, 'The Illusion of Economic Structure: Craft Guilds in Late Medieval English Towns', Past and Present 121 (1988): 44.

4 Records of Early English Drama: York, Alexandra F. Johnston and Margaret Rogerson (eds), 2 vols (Toronto, 1979), 1:396. This record is dated 1580, but see 1:118 for a 1478 record of fines threatened for not upholding the Shipmen's Noah pageant. Subsequent references to this collection of dramatic records will be identified as REED: York.

5 D.M. Palliser, Tudor York (Oxford, 1979), 112. For implications with regard to drama, though with a different emphasis than mine, see Johnston, 'The City as Patron: York', esp. 156-66.

6 W.G. Hoskins, Local History in England, 3rd ed (London, 1984), 278. In 1377, York had been ranked first among provincial cities (277).

7 E. Miller, 'Medieval York', in A History of Yorkshire: The City of York, R.B. Pugh (ed), Victoria History of the Counties of England (London,1961), 90, 114-16 ; for freemen's admissions, see Register of the Freemen of the City of York, Francis Collins (ed), Surtees Society 96, 102 (Durham, 1897-1900), and the discussion in R.B. Dobson, 'Admissions to the Freedom of the City of York in the Later Middle Ages', Economic History Review, 2nd ser. 26 (1973): $1-21$.

8 York Civic Records, Angelo Raine et al. (eds), 9 vols (York, 1939-78): 2:81.

9 See especially Charles Phythian-Adams, Desolation of a City: Coventry and the Urban Crisis of the Late Middle Ages (Cambridge, 1979).

10 REED: York, 1:332.

11 REED: York, 1:356.

12 York Civic Records, 5:89.

13 REED: York, 1:307.

14 Ibid., 1:23, 26.

15 York Civic Records, 6:13; see also Palliser, Tudor York, 162.

16 The useful term 'traditional religion' was introduced by Eamon Duffy, The Stripping of the Altars: Traditional Religion in England 1400-1580 (New Haven, 1992). 
17 REED: York, 1:313.

18 REED: York, 1:314-15.

19 See Miller, 'Medieval York', 108-9; Palliser, Tudor York, 128-31; Dobson, 'Admissions to the Freedom', 11.

20 Chester Scoville, 'But owthir in frith or feld: The Rural in the York Cycle', Comparative Drama 37 (2003): 185.

21 Palliser, Tudor York, 120; D.M. Palliser, 'Urban Decay Revisited', in Towns and Townspeople in the Fifteenth Century (Gloucester, 1988), 1-21; Creighton Gilbert, 'When Did a Man in the Renaissance Grow Old?' Studies in the Renaissance 14 (1967): 7-32. The town elite, unsurprisingly, fared much better than those with lesser means with regard to infant mortality and age at death.

22 Christopher Dyer, Standards of Living in the Later Middle Ages: Social Change in England c.1200-1520, revised ed (Cambridge, 1998), 192.

23 REED: York, 1:303. See also Francis Drake, Eboracum; or, The History and Antiquities of the City of York (London, 1736), 128.

24 Miller, 'Medieval York', 85; D.M. Palliser, 'Epidemics in Tudor York', Northern History 8 (1973): 45-63.

25 REED: York, 1:3.

26 Charles Creighton, A History of Epidemics in England, 2nd ed, 2 vols (New York, 1965), 1:218.

27 Thomas Walsingham, Historia Anglicana, H.T. Riley (ed), 2 vols, Rerum Britannicarum Medii Aevi Scriptores 28B (London, 1863-4), 2:203; previously noted by Creighton, $A$ History of Epidemics, 1:220.

28 See Mervyn James, Family, Lineage, and Civil Society (Oxford, 1974), 8; W.G. Howson, 'Plague, Poverty, and Population in Parts of North-West England, 1580-1720', Transactions of the Historic Society of Lancashire and Cheshire 92 (1961): 37.

29 Dobson, 'Admissions to the Freedom', 17; Register of the Freemen of the City of York, 1:153-63.

30 Robert S. Gottfried, Epidemic Disease in Fifteenth Century England (New Brunswick, 1978), 38.

31 Palliser, Tudor York, 122-3. The match between harvest failure, nationwide epidemic, and local disease is not at all exact. See, for example, W.G. Hoskins, 'Harvest Fluctuations and English Economic History, 1480-1619', Agricultural History Review 12 (1964): 28-46. It should also be noted that other causes of food shortage and high prices of certain commodities must be taken into account - eg, diseases of sheep and cattle, which reduced the availability of protein, or weather unfavorable to the various fruits that made up a substantial 
portion of the diet. And, as Paul Slack has noted, 'Not every crisis followed a dearth: there were occasional years of high mortality in the middle of a run of good harvests. ... But virtually every bad harvest appears to have been followed by a period of high mortality' ('Mortality Crises and Epidemics, 1485-1610', in Health, Medicine and Mortality in the Sixteenth Century, Charles Webster (ed) (Cambridge, 1979), 16-17).

32 York Civic Records, 2:102.

33 Palliser, 'Epidemics in Tudor York', 46-7; Hoskins, 'Harvest Fluctuations and English Economic History', 44.

34 York Civic Records, 4:30.

35 Palliser, 'Epidemics in Tudor York', 45-63.

36 York Civic Records, 5:29.

37 Drake, Eboracum, 128. See also John Stow, Annales, or a Generall Chronicle of England (London, 1631), 506-7, for confirmation of sudden death by this disease.

38 The Dance of Death, Florence Warren (ed), EETS, o.s. 181 (London, 1931), 47.

39 Palliser, 'Epidemics in Tudor York', 49; for the arrival of the contingent of German soldiers, said to number one thousand, see York Civic Records, 5:24.

40 See, for example, York Civic Records, 5:177-8, and on crop failures see also Hoskins, 'Harvest Fluctuations and English Economic History,' 35-6.

41 Palliser, 'Epidemics in Tudor York,' 49-50; see also Hoskins, 'Harvest Fluctuations and English Economic History,' 35-6, 45.

42 Palliser, 'Epidemics in Tudor York', 51, citing York City Archives, B.22, fol. 131r.

43 REED: York, 1:353. Dean Hutton regarded the people of York to be, like other Northerners, unsound in religion generally and in their ignorance given to superstition, by which he meant traditional Roman Catholic practices; see J.C.H. Aveling, Catholic Recusancy in the City of York, 1558-1791 (London, 1970), 33-4, 50-1.

44 REED: York, 1:393.

45 R.B. Dobson, 'Craft Guilds and City: The Historical Origins of the York Mystery Plays Reassessed,' in The Stage as Mirror: Civic Theatre in Late Medieval Europe, Alan E. Knight (ed) (Cambridge, 1997), 91-105, esp. 103. See also the important comments of Alexandra F. Johnston, 'The York Cycle and the Libraries of York,' in Caroline Barron and Jenny Stratford, (eds), The Church and Learning in Late Medieval Society: Essays in Honour of Barrie Dobson, Harlaxton Medieval Studies 11 (Donington, 2002), 355-70. For 
another recent view of the origin of the York plays, see Jeremy Goldberg, 'Craft Guilds, the Corpus Christi Play and Civic Government', in The Government of Medieval York: Essays in Commemoration of the 1396 Royal Charter, Sarah Rees Jones (ed) (York, 1997), 141-63. The theory that the plays evolved out of non-dramatic pageant wagon processions, as advanced by Martin Stevens ('The York Cycle: From Procession to Play', Leeds Studies in English ns 6 [1972]: 37-61), is not viable.

46 Statutes of the Realm, 11 vols (1810-28; reprint London, 1963), 1:379. This legislation is cited by Swanson, 'The Illusion of Economic Structure', 33.

47 REED: York, 1:387

48 Swanson, 'The Illusion of Economic Structure', 42.

49 REED: York, 1:188-9.

50 For the indispensable role of the different skills contributed by the artisans to play production, see Clifford Davidson, Technology, Guilds, and Early English Drama (Kalamazoo, 1996).

51 Madeleine Hope Dodds, The Pilgrimage of Grace 1536-1537 and the Exeter Conspiracy 1538, 2 vols (Cambridge, 1915), 1:178-85; Palliser, Tudor York, 256-7; Aveling, Catholic Recusancy in the City of York, 1-47; Johnston, 'The City as Patron: York', 163-7. The plays were deeply embedded in Northern spirituality, as I argued nearly a generation ago ('Northern Spirituality and the Late Medieval Drama of York', in The Spirituality of Western Christendom, E. Rozanne Elder (ed) (Kalamazoo, 1976), 125-50; subsequently reprinted in my On Tradition: Essays on the Use and Valuation of the Past (New York, 1992), 30-55) and in more recent publications. Valuable commentary is contained in J.W. Robinson, Studies in Fifteenth-Century Stagecraft (Kalamazoo,1991), and recently with specific emphasis on the York civic context in Johnston, 'The York Cycle and the Libraries of York', 355-70.

52 See, for example, J.S. Purvis, Tudor Parish Documents of the Diocese of York (Cambridge, 1948), 187, regarding the church of St Mary Bishophill Sr, and Aveling, Catholic Recusancy in the City of York, 26.

53 A convenient brief biography and bibliography are contained in David Hugh Farmer, The Oxford Dictionary of Saints (Oxford, 1978), 84-5.

54 See Mary Douglas, Natural Symbols (New York, 1982), 51, and Clifford Davidson, 'Positional Symbolism and English Medieval Drama', Comparative Drama 25 (1991): 66-76.

55 See Clifford Davidson and David E. O'Connor, York Art: A Subject List (Kalamazoo, 1978), 54, 58-60, fig. 16; Miriam Skey, 'Herod the Great in Medieval European Drama', Comparative Drama 17 (1983): 330-64, and 
'Herod's Demon Crown', Journal of the Warburg and Courtauld Institutes 40 (1977): 274-6.

56 See Elza Tiner, 'English Law in the York Trial Plays', in The Dramatic Tradition of the Middle Ages, Clifford Davidson (ed) (New York, 2004): 140-9.

57 See the discussion in Ann Eljenholm Nichols, 'The Bread of Heaven: Foretaste or Foresight?' in The Iconography of Heaven, Clifford Davidson (ed) (Kalamazoo, 1994), 40-68.

58 See Miri Rubin, Corpus Christi: The Eucharist in Medieval Culture (Cambridge, 1991). The feast of Corpus Christi was first advocated by the Archbishop of York in 1322 (200).

59 Testamenta Eboracensia, ed James Raine and John W. Clay, 6 vols, Surtees Society 4, 30, 45, 53, 79, 106 (Durham, 1836-1902), 2:230-1.

60 See especially Sixten Ringbom, 'Devotional Images and Imaginative Devotions', Gazette des Beaux-Arts 111 (1969): 159-70.

61 Miller, 'Medieval York,' 107.

62 Angelo Raine, Mediaeval York (London, 1955), 104.

63 Testamentia Eboracensia, 2:151, 5:101.

64 Raine, Mediaeval York, 153, 183, 228-9, 295; Testamenta Eboracensia, 5:191; Davidson and O'Connor, York Art, 84.

65 Testamenta Eboracensia, 2:28.

66 Raine, Mediaeval York, 153.

67 Raine, Mediaeval York, 46; Testamenta Eboracensia, 1:28.

68 Raine, Mediaeval York, 277.

69 Raine, Mediaeval York, 123; Testamenta Eboracensia, 4:77-8.

70 Raine, Mediaeval York, 238, 248-9.

71 York Memorandum Book A/Y, 1:49, 74, 87, as cited by Miller, 'Medieval York', 96.

72 REED: York, 1:124.

73 Davidson and O'Connor, York Art, 116.

74 See E.A. Gee, 'The Painted Glass of All Saints' Church, North Street, York', Archaeologia 102 (1969): 162-4, pls. XXV-XXVI, and Pamela M. King, 'York Plays, Urban Piety and the Case of Nicholas Blackburn', Archiv für das Studium der neueren Sprachen und Literaturen 232 (1995): 37-50. For Blackburn's will, see also Testamenta Eboracensia, 2:17-21, and for chantries established by his beneficence at the Dominican friary see York Memorandum Book B/Y, Joyce Percy (ed), Surtees Society 186 (1973), 155-6. 
75 Line 266 is missing from Beadle's edition, and is supplied here from the list of corrections to the text in Gerald Byron Kinneavy, A Concordance to The York Plays (New York, 1986), xxxii.

76 For the regulation of beggars and the concern that charity be given only to the worthy poor, see York Civic Records, 3:111, 4:30, 93, 145. Attitudes toward charity are discussed in Dyer, Standards of Living, 238-40.

77 REED: York, 1:37.

78 REED: York, 1:109.

79 REED: York, 2:698 (translation from 1:11).

80 REED: York, 2:713 (translation from 1:28).

81 Sarah Rees Jones, 'York's Civic Administration, 1354-1464', in The Government of Medieval York, Rees Jones (ed), 138.

82 For the use of odor in association with hell mouth, required as part of the Barkers' play, see Thomas H. Seiler, 'Filth and Stench as Aspects of the Iconography of Hell,' in The Iconography of Hell, Clifford Davidson and Thomas H. Seiler (eds) (Kalamazoo: Medieval Institute Publications, 1992), 132-40.

83 Pamela M. King, 'Seeing and Hearing; Looking and Listening', Early Theatre 3 (2000): 156. The iconography of the York plays is extensively surveyed in Clifford Davidson, From Creation to Doom: The York Cycle of Mystery Plays (New York, 1984).

84 Dobson, 'Craft Guilds and City,' 104.

85 See the discussion in Alan D. Justice, 'Trade Symbolism in the York Cycle', Theatre Journal 31 (1979): 47-58, but Johnston more astutely has observed that the assignment of some pageants to specific guilds was based on their 'access to the needed set pieces' and properties ('The City as Patron: York', 151-2) - a point implicit in my Technology, Guilds, and Early English Drama.

86 York Memorandum Book A/Y, 1:238, as quoted in translation by Justice, 'Trade Symbolism,' 49.

87 York Memorandum Book B/Y, 254; Justice, 'Trade Symbolism', 49.

88 REED: York, 2:732 (translation of Latin text, ibid., 1:46-7). The pageant and its iconography are discussed by Mark R. Sullivan, 'The Missing York Funeral of the Virgin', in The Dramatic Tradition of the Middle Ages, 150-4.

89 REED: York, 1:110.

90 REED: York, 1:136, 215-17.

91 REED: York, 1:297, 331-2.

92 Miller, 'Medieval York', 82. 
93 A.G. Dickens, 'Tudor York', in A History of Yorkshire: The City of York, 137-8; for the new charter which was adopted in 1517-18, see Drake, Eboracum, 207.

94 Dickens, 'Tudor York', 140.

95 Within the context of play production, the system of civic patronage functioned somewhat differently from the Early Modern system described by Suzanne R. Westfall, "“The useless dearness of the diamond”: Theories of Patronage Theatre', in White and Westfall (eds), Shakespeare and Theatrical Patronage, 13-42, in spite of the relevance of some of her comments.

96 D.M. Palliser, 'The Trade Guilds of Tudor York', in Crisis and Order in English Towns, 1500-1700, Peter Clark and Paul Slack (eds) (Toronto, 1972), 106.

97 See York Civic Records, 5:76-8.

98 See T.P. Cooper, 'The Medieval Highways, Streets, Open Ditches, and Sanitary Conditions of the City of York', Yorkshire Archaeological Journal 22 (1912-13): 271-80, and for the waste disposal ordinance of 1524, see York Civic Records, 3:95-6.

99 Miller, 'Medieval York', 107; Dickens, 'Tudor York', 119; York Civic Records, 5:23, 129; York Memorandum Book B/Y, 217-18.

100 English Historical Documents, 1485-1558, C.H. Williams (ed) (London, 1967), 954.

101 Miller, 'Medieval York', 107, citing York Memorandum Book A/Y, 1:14f, 17f, 39, 164. Cooper quotes (in translation) the Calendar of Close Rolls, 1332-33, regarding Edward III's detestation of 'the abominable smells abounding in the said city [York], more than in any other city of the realm, from dung and manure, and other filth and dirt ...' ('Medieval Highways, Streets', 274).

102 See Meg Twycross, 'Places to hear the play': Pageant Stations at York, 1398-1572', REED Newsletter 3, no. 2 (1978): 10-33; Eileen White, 'Places for Hearing the Corpus Christi Play in York', Medieval English Theatre 9 (1987): 23-63.

103 York Civic Records, 3:110; Dickens, 'Tudor York', 119.

104 See the perspective presented in Robert S. Gottfried, Epidemic Disease in Fifteenth Century England (New Brunswick: Rutgers University Press, 1978), 47-52.

105 Palliser, 'Epidemics in Tudor York', 62. It is, however, important not to paint too grim a picture of life in medieval and early modern York. D.M. Palliser, like many others, has warned of the difficulty of grasping the reality of life as it was actually lived; see his 'Civic Mentality and the Environment in Tudor York', Northern History 18 (1982): 78-115, esp. 78. 
106 The civic procession was one of three processions on Corpus Christi; see Douglas Cowling, 'The Liturgical Celebration of Corpus Christi in Medieval York', REED Newsletter 1, no. 2 (1976): 5-9.

107 British Library numbering. Color facsimiles of these pages appear in The York Play: A Facsimile of British Library MS 35290 (Leeds, 1983), which also contains discussion of the music by Richard Rastall (xli-xlv). See also Rastall's comments in The Heaven Singing, Music in Early English Religious Drama, 1 (Woodbridge, 1996), 121-37.

108 For the phrasing, 'this transitory life,' on the occasion of the death of a mayor in office in 1505 and 1508, see York Civic Records, 3:11, 25.

109 Lawrence M. Clopper, Drama, Play, and Game: English Festive Culture in the Medieval and Early Modern Period (Chicago, 2001), 207.

110 Davidson and O'Connor, York Art, 77-80, fig. 22. The glass dates from the fifteenth century, when St Saviour's Church was entirely rebuilt; see Raine, Mediaeval York, 76-8. 